\title{
KONSEP ANAK TENTANG TUHAN
}

\author{
Subandi \\ Universitas Gadjah Mada
}

\begin{abstract}
Religious psychologists, commonly believe that human being has religious instinct; a potentionality that naturrally brings human to a religious iffe. The Islamic psychologists also agree that human are bom with "fitrah" which mean, bassic believe in the existence of God. This potentionality development infeunce by how muach he/she is stimualated cognitively understand about God.

This article ty $b$ discuss rellgious life in childhood, specifically child concept about God in specific according to several experts such as: Harms, Goldman and Deconchy. This article stresses that the concept of God is abstract to children, but early understood concretely. Along with the stimulus and learning received by children, they show their ability to think about God abstractly or formal operational in Piaget.s term.
\end{abstract}

Keywords: Concept of God, Children.

\section{Pengantar}

Ajaran agama sering tampil dengan ungkapan yang abstrak. Salah satu contohnya adalah ungkapan "Tuhan itu satu, dekat dan berada đ mana-mana". Bagi anakanak, khususnya yang berusia di bawah 10 tahun, pengertian dekat tanpa adanya wujud kongkrit cukup menyulitkan untuk dipahami. Anak-anak mengartikan dekat adalah sesuatu yang terjangkau oleh indra mereka. Begitu pula dengan ungkapan satu dan berada d mana-mana, anak-anak akan bingung karena tidak mampu membayangkan sesuatu yang satu tapi ada di mana-mana. Dalam konsep anak-anak, satu berarti berada di suatu tempat dan tidak berada di tempat lain. Untuk memperjelas masalah tersebut, akan dilakukan analisis dari para ahli tentang proses pembentukan konsep Tuhan pada anak-anak sehingga akhirnya dapat memiliki pemahaman yang menyeluruh tentang Tuhan.

\section{Proses Imitasi Hingga Bertanya Secara Kritis}

Pengaruh lingkungan, terutama keluarga, memang sangat dominan bagi perkembangan keberagamaan seseorang.
Seorang anak yang dibesarkan dalam keluarga yang religius akan lebih besar kemungkinannya berkembang menjadi lebih religius dibandingkan dengan yang hidup di keluarga yang tidak religius. Anak yang dilahirkan dalam keluarga yang beragama Islam, secara otomatis religious instinct yang dimiliki berkembang dalam tradisi islam dan kemungkinan besar dia akan menjadi seorang muslim yang baik. Demikian juga jika seorang anak dilahirkan dalam keluarga Kristen, Katolik, Hindu atau Buddha. Meskipun demikian ada beberapa perkecualian di mana perkembangan keberagamaan menyimpang dari pengaruh lingkungan (keluarga). Misalnya pada kasus konversi agama, yaitu pindah afiliasi agama maupun peningkatan secara drastis dari nonreligius ke rellgius.

Mekanisme psikologis kehidupan beragama pada masa kanak-kanak yang sangat menonjol adalah mekanisme imitasi. Seperti perkembangan aspek-aspek psikologis dan kemampuan anak yang lain yang berkembang lewat proses peniruan, pada mulanya, anak-anak beragama karena meniru orang tuanya. Oleh karena itu Clark (1958) menyebutkan bahwa salah satu ciri kehidupan beragama pada masa kanak- 
kanak adalah sifatnya yang imitatif. Artinya, anak-anak hanya menirukan apa yang diyakini dan dilakukan orangtuanya. Dengan dem/kian jika anak-anak melakukan suatu ibadah (pergi ke masjid, gereja, kuil atau biara), maka semua itu dilakukan hanya karena meniru orangtuanya. Belum ada satu keseriusan dalam diri anak-anak untuk melakukan ritual keagamaan seperti orang dewasa.

Menurut Clark (1958), jika seorang anak melakukan ritual keagamaan, maka ha! ini hanya bersifat superfisial saja. Meskipun ada beberapa anak yang seakan-akan menunjukkan perilaku yang sangat religius, di antaranya rajin melaksanakan ritual keagamaan (misalnya sholat dalam agama Is[am), tetapl apa yang mereka lakukan itu pada umumnya baru merupakan suatu kebiasaan saja. Pemahaman dan penghayatan secara mendalam tentang ajaran agama masih belum ada. Mereka dalam menjalankan ajaran agama masih bersifat ritualistik semata. Bagi pendidikan agama, hal ini merupakan proses belajar yang sangat baik agar orang menjadi religius.

Selain tampak pada peribadatan ritual suatu agama, proses imltasi dalam kehidupan beragama anak-anak tampak juga pada penerimaan keyakinan agama yang diajarkan pada mereka. Thun (Wulff, 1991) mengemukakan bahwa kehidupan beragama anak-anak sangat tergantung pada faktor lingkungan. Anak-anak menerima agama bukan berdasarkan pertimbangan raslonal atau teologis, melainkan semata-mata ditentukan oleh hubungan anak-anak dengan orang dewasa di sekitarnya. Clark (1958) menyebut ciri kehidupan beragama anak-anak ini bersifat autoritatif, karena keberagamaan anak-anak masih didominasi oleh keberagamaan orang dewasa di sekitarnya, terutama orangtuanya.

Meskipun anak-anak menerima ajaran agama secara apa adanya, tanpa memikirkan lebih jauh tentang kebenarannya, telapi hal ini bukan berarti anak-anak tidak pernah mengajukan pertanyaan tentang masalah agama. Dalam penelitiannya, Zeligs (1974) mengumpulkan sejumlah pertanyaan yang sering diajukan anak-anak dalam kaitan dengan kehidupan beragama, terutama tentang konsep Tuhan. Hasil penelitiannya menunjukkan bahwa pertanyaan-pertanyaan itu kadang sangat kritis. Beberapa pertanyaan yang sering diajukan itu antara lain: Apakah Tuhan itu seperti manusia biasa? Bagaimana Tuhan membuat diri-Nya sendiri? Bagaimana Tuhan bangun of langit? Berapa umur-Nya? Apakah Dia seorang Kristen atau Yahudl atau Muslim? Apakah Tuhan seperti manusia? Bisakah Tuhan didekap?

Pertanyaan-pertanyaan yang diajukan oleh anak-anak seperti terungkap dalam penelitian Zeligs (1974) di atas, menurut Paloutzian (1984) bukanlah merupakan pertanyaan yang serius, dalam arti bahwa anak-anak bukannya menanyakan tentang kebenaran ajaran yang diterimanya, melainkan lebih banyak dldorong oleh rasa ingin tahu (curiosity) belaka.

\section{Berpikir Konkrittentang Tuhan}

Selaln dipengaruhi oleh lingkungan di sekitarnya, kehidupan beragama pada masa kanak-kanak juga banyak dipengaruhi oleh perkembangan kognisinya. Pada masa ini anak memahami segala sesuatu yang abstrak akan diinterpretaslkan secara konkrit. Misalnya pengertian kasih sayang akan dipahami sebagai pemberian hadiah ulang tahun. Hal inl juga berpengaruh pada kehidupan beragama mereka.

Anak-anak memahami konsep-konsep abstrak dalam agama sebagai suatu bentuk yang konkrit. Anak-anak memahami konsepkonsep supranatural dalam agama (misalnya Tuhan, surga, neraka, malakkat, dan sebagainya) sebagal suatu bentuk konkret seperti yang ada dalam kehidupan seharihari. Oleh karena itu tidak heran jika ada seorang anak yang menggambarkan surga seperti sebuah superrnarket, di mana anakanak dapat memperoleh es krim, chiki atau permen karet yang mereka senangi. Ketika seorang anak mendapat pelajaran bahwa surga itu di bawah telapak kaki ibu, maka ia segera pulang dan meminta ibunya tiduran supaya dia bisa melihat surga di bawah telapak kaki ibunya.

Berkaitan dengan perkembangan 
kognisi, masa kanak-kanak adalah masa yang penuh dengan imajinasi. Anak-anak sangat senang cerita-cerita fantasi, terutama yang bersifat magical. Mereka senang sekali mendengar kisah-kisah keagamaan yang mengandung unsur supranatural. Misalnya cerita tentang bidadari dan taman surga yang penuh dengan aneka kenikmatan, cerita tentang kehebatan Nabi Musa yang tongkatnya bisa menjadi ular dan dapat membelah laut tengah. Karakterisitik kehidupan beragama masa kanak-kanak yang juga sangat menonjoi adalah sifat egosentris. Anak-anak pada umumnya mengartikan agama sesuai dengan kebutuhannya. Tuhan sering dipersepsikan sebagai sesuatu yang dapat memenuhi kebutuhan dirinya. Hal ini tampak jelas pada pada waktu anak-anak berdoa. Penelitian Long dkk. (1968) menunjukkan bahwa bagi anak-anak doa senantiasa dikaitkan dengan suatu aktivitas konkret tertentu yang sesuai dengan kebutuhan pribadinya. Anak-anak temyata banyak berdoa untuk hal-hal yang bersifat egosentris, misalnya untuk mendapatkan mainan atau kesenangannya yang lain. Kesadaran untuk melaksanakan doa sebagai wujud pengabdian kepada Tuhan tampaknya masihjauh dari jangkauan mereka.

\section{Konsep Anak Tentang Tuhan Menurut Harms}

Para ahli psikologi agama telah meiaksanakan berbagai macam penelitian empiris maupun melaksanakan analisis teoritik berkaitan dengan tahap-tahap perkembangan keberagamaan anak, khususnya konsep anak tentang Tuhan. Penelitian paling awal dilakukan oieh Harms (Paloutzian, 1997) pada tahun 1944. Hasii penelitian ini menunjukkan bahwa ada tiga tahap perkembangan konsep tentang Tuhan pad a anak dan remaja.

Pertama, tahap dongeng (fairy-tales stage). Tahap ini terjadi pada usia 3-6 tahun. Anak menggambarkan Tuhan seperti ceritacerita lain dalam dongeng yang dia dengar, $\mathrm{m} \mid$ salnya manusia bersayap, raksasa atau hantu. Hai int bisa dimengerti karena pada usia ini yang paling dominan pada anak adalah kemampuan fantasi. Tradisi mendongeng sebelum tidur yang terdapat hampir di semua budaya menunjukkan kesenangan anak kepada dongeng. Ketika mendengar dongeng-dongeng itulah anak kemudian berfantasi dengan dunianya sendiri. Mereka belum bisa membedakan antara dunia nyata dan dunia dongeng. Oleh karena itu ketika mendegarkan cerita-cerita keagamaan yang berkaitan dengan Tuhan, maka anak menyamakan begitu saja seluruh isi cerita itu dengan dongeng-dongeng yang lain.

Kedua, tahap realistik (realistic stage). Tahap ini terjadi pada umur $7-12$ tahun. Pada umumnya anak-anak di usia ini telah pergi ke sekolah. Mereka sudah mulai mendapatkan pelajaran-pelajaran yang merangsang intelektualitasnya, tetapi pemahaman kognitifnya masih sangat konkrit. Hal-hal yang abstrak dipahaminya secara apa adanya, sehingga gambaran anak tentang Tuhan pada masa ini bersifat konkrit dan antropomorphis. Anak sering mengasosiasikan Tuhan sebagai orang besar dan sudah tua yang tinggal of langit (Paloutzian, 1984). Maclean (Clark, 1958) menemukan dalam penelitiannya bahwa $73 \%$ anak-anak yang diteliti menyetujui bahwa Tuhan itu mempunyai muka, tangan, kaki seperti manusia. Sementara yang lainnya mengemukakan bahwa Tuhan itu sama sekali tidak seperti manusia, melainkan seperti listrik atau seperti energi yang senantiasa membuat segala sesuatu bisa bekerja atau bisa tumbuh dengan baik. Demikian juga ketika orangtua mengajarkan bahwa Tuhan itu Maha Besar, ternyata banyak anak yang menginterpretasikan bahwa Tuhan itu mempunyai badan yang besar seperti raksasa.

Ketiga, tahap individualistik (individualitic stage). Tahap ini terjadi pada umur $13-18$ tahun, di mana anak pada umumnya sekolah di tingkat Sekoiah Menengah. Tahap ini secara garis besar terdiri dari tiga keiompok. Kelompok pertama yaitu anak-anak yang memiliki gambaran Tuhan dengan mengikuti gambaran Tuhan secara formal dari orangorang yang ada di sekitamya. Kelompok ini lebih bersifat konvensional dan konservatif. 
Kelompok kedua adalah yang memandang Tuhan dalam gambaran yang bersifat mistis. Ketika disuruh menggambarkan tentang Tuhan anak-anak ini menggambar cahaya atau awan. Kelompok ketiga adalah anakanak yang lebih memperhatikan simbolsimbol keagamaan dalam menggambarkan tentang Tuhan.

\section{Konsep Anak Tentang Tuhan Menurut Goldman}

Penelitian Harms di atas telah memberikan rangsangan bagi peneliti lain seperti Ronald Goldman pada tahun 1964 (Paloutzian, 1997). Mereka melaksanakan wawancara pada 200 anak yang berumur 6 sampai 16 tahun, berkaitan dengan gambargambar yang bersifat religius dan ceritacerita dalam Injil. Seperti Harms, Goldman juga menyimpulkan adanya tiga tahap perkembangan agama pada anak-anak dan remaja. Istilah dan analisis yang digunakan oleh Goldman mengacu kepada teori perkembangan kognitif dari Plaget.

Goldman (Paloutzian, 1997) menyebut tahap pertama keagamaan anak adalah preoperational intuitive thought (pemikiran intuitlf operasional) yang terjadi pada umur 6 - 8 tahun). Tahap ini dicirikan oleh pemikiran keagamaan yang bersifat tidak sistematis dan fragmental. Hal ini karena mereka belum bisa melihat ajaran agama secara menyeluruh. Misalnya ketika ditanya, "Mengapa Nabi Musa takut kepada Tuhan," (disebutkan dalam Eksodus 3:6), mereka menjawab "karena Tuhan mempunyai wajah yanglucu".

Tahap kedua oleh Goldman (Paloutzian, 1997) disebut concrete operational thought (pemikiran operasional konkret) yang terjadi pada usia 8- 14 tahun. Pada kelompok umur ini subjek penelitian Goldman lebih memfokuskan pada hal-hal spesifik dari gambar yang ditunjukkan. Ketika ditanya tentang kenapa Nabi Musa takut kepada Tuhan dalam cerita Injil itu, mereka menjawab secara konkret dengan mengacu kepada cerita itu kembali. Mereka menjawab: "Karena pada saat itu ada bola api dan Nabi Musa takut api itu akan membakarnya." Ada juga yang menjawab; "Karena waktu itu ada cahaya yang terang benderang, sehingga kalau Nabi Musa melihatnya akan membuat diabuta."

Tahap ketiga disebut formal operational thougth (pemikiran operasional formal/abstrak) yang terjadi pada usia 14- 16 tahun. Ketika Goldman mengadakan wawancara dengan anak kelompok umur ini, dia mendapatkan bukti adanya pemikiran abstrak dan hipotetis. Dengan pertanyaan yang sama tentang Nabi Musa di atas, kelompok ini menjawab: "Karena Tuhan adalah Suci, dunia ini penuh dengan dosa," atau "Karena Nabi Musa takjub dengan keMaha-Besar-an Tuhan, sehingga Nabi Musa merasa dirinya seperti seekor cacing di tanah."

\section{Konsep Anak Tentang Tuhan Menurut Deconchy}

Penelitian lain yang berkaitan dengan tahap perkembangan keagamaan dilakukan oleh Deconchy (Spilka dkk, 1987). Dalam penelitian itu Deconchy meminta anak-anak usia 8 - 16 tahun berasosiasi bebas dengan kata Tuhan. Tema respon yang diberikan anak-anak itu ternyata dapat diklasifikasikan kedalam 3 (tiga) kelompok.

Kelompok pertama, tema-tema atributif (attributive themes). Tema ini banyak diberikan oleh anak-anak umur 8 - 10 tahun. Mereka melihat Tuhan sebagai suatu kumpulan sifat-sifat tertentu yang pada umumnya bersifat konkrit antropomorfis. Konsep tentang Tuhan bagi mereka ternyata tidak berkait dengan konsep-konsep agama yang lain.

Kelompok kedua, tema-tema personalisasi (personalization thomes). Terna yang banyak diberikan oleh anak-anak usia $\uparrow 1-\uparrow 3$ tahun ini menunjukkan bahwa mereka melihat Tuhan dalam perspektif yang tidak menekankan aspek-aspek fisik. Mereka mulai dapat melihat hal-hal yang non-fisik.

Kelompok ketiga, tema-tema interiorisasi (interiorization themes). Anak usia 14 - 16 tahun yang banyak membuat tema ini. Konsep anak-anak tentang Tuhan di usia ini sudah lebih abstrak dari mereka yang usianya lebih muda. Konsep yang berkaitan dengan hubungan seseorang dengan Tuhan sudah mulai muncul, baik yang bersifat positif seperti cinta dan kasih sayang maupun yang 
bersifat negatif, seperti keraguan tentang eksistensi Tuhan itu sendiri.

\section{Pembahasan}

Konsep anak-anak tentang Tuhan sangat dipengaruhi oleh perkembangan kognitifnya. Hal ini sebagaimana diungkapkan oleh Harms (Paloutzian, 1997). Goidman (Paloutzian, 1997), dan Deconchy (Splika dkk, 1987). Hasil penelitian yang sejenis diungkapkan oleh Artanto (2006) yang bertopik Konsep Tuhan pada Anak. Usia Akhir Operasional Kongkret. Pada awalnya mereka akan memahami Tuhan sebagai sebuah konsep konkrit-anthropomorfis, yang mempunyal perwujudan rili dan memiliki sifat seperti manusia. Kosep ini sedikit demi sedikit berubah lebih abstrak sesual dengan perkembangan kognitifnya. Dengan demikian konsep yang abstrak seperti Tuhan itu satu, dekat dan berada di mana-mana pada awalnya dipahami anak dengan persepsinya sendiri yang masih konkrit. Lama kelamaan, mereka akan dapat memahami konsep tersebut secara abstrak. Kemampuan berpikir abstrak bahkan dapat diperoleh lebih awal bila rangsangan kognitif yang diterima anak, baik rangsangan kognitif yang langsung berkaitan dengan konsep ketuhanan maupun rangsangan kognitif pada umumnya, akan mempercepat hadirnya kemampuan berpikir abstrak dalam diri anak. Hal ini secara jelas terlihat dari subjek penelitian Artanto (2006) dimana pada usia 10-11 tahun mereka telah menunjukkan kemampuan berpikir operasional-formal (formal/abstract operational thought).

Ketika seseorang memasuki masa dewasa bukan berarti karakteristik seperti ini hilang semua. Banyak orang yang meskipun sudah memasuki masa dewasa, tetapi konsepnya tentang Tuhan belum beranjak dari sifat konkrit antropomorfis. Demikian juga penelitian-penelitian yang dikemukakan d dalam tulisan ini (Harms dalam Paloutzian, 1997; Goldman dalam Paloutzlan, 1997; dan Deconchy dalam Spilka dkk, 1987) berasal dari latar belakang agama Kristen yang memiliki konsep ketuhanan yang dekat dengan konsep konkret-anthropomorphis.

Oleh karena itu sangat penting untuk memahami bagaimana konsep Tuhan pada anak-anak dengan latar belakang agama yang berbeda, khususnya Islam yang memiliki konsep ketuhanan yang lebih abstrak. Hasil penelitian Artanto (2006) membantu kita untuk memahami anak-anak yang bertatar belakang agama Islam. Kalau dicermati, dapat diketahui anak-anak muslim memperoleh rangsangan kognitif atau pengajaran agama sejak dini dari orangtua dan lembaga pendidikan. Hasil penelitian Artanto juga menunjukkan bahwa gagasan Tuhan yang dikemukakan anak cenderung menyiralkan kemahakuasaan Tuhan yang memang menjadi ciri dari ajaran Islam. Dalam konsep anak, Tuhan adalah pengatur, pemilik segalanya, sesuatu terjadi atas kehendak dan izin-Nya.

Demikian pandangan yang dapat penulis sampaikan. Wallahu a'lam bi ash-shawab.

\section{Daftar Pustaka}

Alport, G. W. 1950. The Individual and his Religion: a Psychological inferprefation. New York The Macmillan Co.

Artanto, D.R. 2006. Konsep TuhanpadaAnak. Jumal Psikologika, XXI, (1), 5-21.

Clark, H. W. 1958. An Introduction b The Psychology of Religion: an introduction to Religious Experience and Behaviour. New York: The Macmillan Company.

Johnson, P. E. 1945. Psychology of Religion. New York: Abingdon-Cokesbury Press.

Long, D., Elkind, D., \& Spilka, B. 1967. The Child Conception of Prayer. Journal for the Scientific Study of Religion. 6 , 101-109.

Paloutzian, R F. 1984. Invilation to the Psychology of Religion. Glenview, Iflinois: Foreman \& Company.

Paloutzian, R.F. 1997. Invitation to the Psychology of Religion. Boston: Aliyn and Bacon.

Wulf, D. M. 1991. Psychology of Religion: Classic and Confemporary Views. New York: John Wiley \& Sons.

Zeligs, R. 1974. Children Experience With Death. Springfield, Illinois: Charles C. Thomas. 